\title{
COMMENTARY
}

\section{The Nostalgia of Pencils, Chalk, and Typewriters}

\author{
Frank Romanelli, PharmD, MPH ${ }^{\mathrm{a}, \mathrm{b}}$ \\ ${ }^{\text {a }}$ University of Kentucky, College of Pharmacy, Lexington, Kentucky \\ ${ }^{\mathrm{b}}$ Executive Associate Editor, American Journal of Pharmaceutical Education, Arlington, Virginia
}

Corresponding Author: Frank Romanelli, University of Kentucky, College of Pharmacy, 789 South Limestone Rd., Lexington, KY 40536. Tel: 859-338-3911. Email: froma2@uky.edu

Submitted June 24, 2021; accepted June 28, 2021; ePublished July 2021

Nostalgia is characterized by feelings of sentimentality and wistful speaking. Once considered pathologic, nostalgia is now recognized to be a normal and perhaps essential part of the human condition. Closely related to but distinct from nostalgia is a phenomenon known as 'rosy retrospection.' Rosy retrospection is a bias where individuals judge the past as being disproportionally superior to the present. Nostalgia plays a role in helping individuals and society gauge its progress and accomplishments. It also serves to offer comfort in difficult times. Individuals should be careful to understand the differences between nostalgia and rosy retrospection and in turn make efforts to build nostalgic moments with colleagues and family members both inside and outside of the classroom.

Keywords: nostalgia; education

As a child I always had an affinity for office supplies. When other kids were asking their parents for bicycles, trains, or electric race car sets all I wanted was a chalkboard. I still remember buying my first red pan. Maybe it is my affinity for office supplies that always draws me towards the nostalgia of classrooms but many times it seems to be a common theme amongst educators. I often wonder if nostalgia is a repeating phenomenon that cycles through each generation. Will our current students someday long for the "good old days" of dry erase boards, two-dimensional zoom calls, and hybrid learning? Regardless, the novelty and mystique of nostalgia seems ever more present all around us. Professional and collegiate sports teams seem to constantly be rotating through versions of "retro" uniforms, popular bygone TV shows are spinning reunion after reunion, and vintage fashion brands seem to lead the list of trendy clothes. Perhaps nowhere was the conjecture of nostalgia more prominent then in both the 2016 and 2020 presential elections where calls were made by some to "Make American Great Again."

Some regard feelings of nostalgia or a sentimentally for the past as being an impediment or a hinderance to progress. In 1688 swiss physician Johannes Hofer first coined the term nostalgia which he further described as a pathology that was intermingled with feelings of homesickness and melancholy. ${ }^{1}$ In 1899 The Lancet published an opinion piece supporting the Royal College of Physicians' decision to exclude nostalgia from its "Nomenclature of Diseases." $"$ Since that time nostalgia has come to be recognized as a normal and universal aspect of the human condition. Psychometric instruments have been developed to measure nostalgia. The Southampton Nostalgia Scale is intended to describe the extent of one's proneness towards nostalgia. ${ }^{3}$

Nostalgia runs parallel to another phenomenon that has been coined 'rosy retrospection. ${ }^{4}$ Rosy retrospection is a tendency to recall the past more fondly than the present. While related to nostalgia, rosy retrospection is unique in that there is an almost unilateral bias towards perceiving the present to be worse than the past. Rosy retrospection is a bias marred with discrepancies in perceptions that involve the denial, discounting, and indifference towards any shortcomings, impediments, or difficulties of associated past events. Some have hypothesized that rosy retrospection occurs because our brains are programmed towards emotionally salient events and memories. For most adults those salient events tend to occur between the ages of 20 and 30. Within this timeframe most adults leave home and travel to college, they may be involved in their most significant relationships, obtain their first job, and marry. Therefore, this period in life becomes for many an emotional bookmark within the mind against which most experiences are compared and contrasted mentally.

By reflecting on the past, nostalgia also plays a part in recognizing our history and certainly helps define progress. Understanding the nuances of a typewriter helps us both mark progress as well appreciate the advantages of modern technology and word processing. Similarly, having used indexus medicus as a literature search tool helps one understand 
the evolution that has occurred in this area. Nostalgia is our collective body of history both personal and public. The practice of constructing and enshrining time capsules is an intentional and systematic nod to nostalgia. Time capsules deliver purposeful messages from the past to the present. They serve to trigger sentimental feelings and memories. By serving as a collective repository of thoughts, events, and history, nostalgia is often the "glue" that binds specific generations together. In much the same way it can serve to demarcate various groups. Parents often remark that children "these days" are just different, and educators are constantly opining over the changes they see in students.

Some investigators have examined the effects of nostalgia on dementia and have hypothesized that reminiscing may serve as a coping mechanism for the untoward effects of memory loss. ${ }^{5}$ Nostalgia may act to make life more meaningful and death less ominous. Speaking wistfully of the past often leads people to be more optimistic and hopeful for the future. A sentimentality for the past can also serve as a coping mechanism when life becomes complicated. Pharmacists often reminisce of the by-gone days of practice where they knew each patient by name and where pharmacies were often outfitted with soda fountains and jerks. New students, residents, and even teachers fall back on what they know both to learn about what is ahead and to garner optimism for the future.

As the pace of the world continues to quicken some have questioned if the speed of change has hastened feelings of sentimentality. The rate at which society continues to evolve and generate new information as well as technological innovations continues to occur at an untethered pace. No clearer example might exist then the remarkable progress which was made in the development and mass manufacturing of mRNA-based vaccines over the last 12 to 24 months. The natural response to feelings that "the world is passing you by" is to long for a time when things may have moved more slowly.

Top chefs aspire to create food that is rich and deep in flavor. Along with flavor, good food is composed of contrasting textures. Nostalgia may be what adds texture to life. Nostalgia helps us to recognize progress and deal with transitions. When we look back, we see how far we have come. Comparisons are not always unhealthy indeed they allow us to see and appreciate growth. Academia's approach to testing has grown leaps and bounds. Many can recall paper and pencil quizzes and tests that morphed to scantron forms and then to electronic platforms and most recently to the use of standardized patients and Objective Standardized Clinical Examinations (OSCEs).

Our default settings may be to avoid or shun wistful thoughts whether they be in our own lives or across the Academy. Often, we find ourselves critical or impatient with colleagues who tend to reminisce comparing classrooms now to classrooms then or practice standards now to practice standards then. But maybe we should be easier on ourselves and our colleagues. It is important to be aware of the biases inherent to rosy retrospection but perhaps nostalgia truly does serve a greater good. If this is the case then maybe we should seek out more opportunities both with our families and our colleagues to experience more nostalgic building moments, times, and events.

\section{REFERENCES}

1. Hofer J. "Medical Dissertation on Nostalgia." Bulletin of the Institute of the History of Medicine. 1934;1688;376391. (Original work published 1688)

2. Batcho KI. Nostalgia: Support or retreat in difficult times? American Journal of Psychology 2013;126:355-367.

3. Routledge C, Arndt J, Sedikides C, et al. A blast from the past: The terror management function of nostalgia. Journal of Experimental Social Psychology 2008;44:132-140.

4. Mitchell TR, Thompson L, Peterson E, et al. Temporal adjustments in the evaluation of events: The "rosy" view. Journal of Experimental Social Psychology 1997;33:421-448.

5. Ismail S, Christopher C, Dodd E, et al. Psychological and Mnemonic benefits of nostalgia for people with dementia. Journal of Alzheimer's Disease 2018;65:1327-1348. 